Sadar et al., Afr J Tradit Complement Altern Med. (2015) 12(4):9-13

http://dx.doi.org/10.4314/ajtcam.v12i4.2

\title{
APPRAISAL OF ETHNOBOTANICAL USES OF THE WETLAND PLANTS OF PUNJAB, PAKISTAN
}

\author{
Andleeb Anwar Sardar ${ }^{1}$, Zaheer-ud-din Khan ${ }^{1}$, Anjum Perveen ${ }^{2}$ and Arifa Zereen ${ }^{1}$ \\ ${ }^{1}$ University of Education Lower Mall Campus Lahore, Pakistan, Department of Botany, Govt College, University Lahore- \\ Pakistan, ${ }^{2}$ Centre for Plant Conservation, University of Karachi, Karachi-Pakistan \\ E-mail: andleebanwar@gcu.edu.pk, Khan_zaheergcu@yahoo.com, arifazereen@yahoo.com. anjum_tahir@hotmail.com
}

\begin{abstract}
Background: Aquatic and semiaquatic plants have a multiplicity of traditional and ethnopharmacological uses ranging from medicinal, famine food to fodder and others. Therefore, the present study was carried out during the years 2008-2011 to document the locally used medicinal, ethnobotanical and traditional data of aquatic and semiaquatic plants of the Punjab, Pakistan.

Material and Method: Various visits of the study area were made to collect the data of these plants included local name, habit and habitat with special emphasis on their therapeutic uses against different human ailments. The local elderly, knowledgable people and herbal healers were also interviewed during the visits.

Results: A total of thirty-four aquatic and semiaquatic plants were collected and out of these, eighteen plants belonging to the three monocotyledonous and fourteen dicotyledonous families were reported to medicinal and food value as well as found useful in making ropes, mats, baskets and soil binding.

Conclusion: The wetland of Punjab (Pakistan) possesses a variety of medicinal plants that are being utilized against various human diseases, e.g. Respiratorial, dermatological, gastrontological, neurological and cardio-vascular diseases.
\end{abstract}

Key Words: Ethnobotanical uses, wetland plants, and herbal medicines.

\section{Introduction}

The substances in plants are used to cure common diseases and their relationship with the ethnic/local people is known as Ethnopharmacology. Holmstedt and Bruhn (1983) consider it as "the interdisciplinary scientific investigation of biologically dynamic agents used or observed by men conventionally ". The knowledge of plants used by Humans is thousands of years old, gained by "trial and error" methods. Medicinal plants are commonly used for survival, home therapies, trade and helpful in lessen human suffering/poverty (Kunwar et al., 2006). In the developing countries of the world which do not have modern health care facilities, medicinal plants play a vital role in the existence of rural peoples (Ahmad, 2003). Conventional medicines obtained from plants meet daily primary health requirements of about 70-80\% indigenous population in the developing countries Worldwide (Eddouks et al., 2002). Ayurvedic and Unani are the two most consistent systems in the field of ethno-medicine that present basic health facilities to the rural people of Pakistan and India.

A variety of herbal medicines have tremendous repute for the treatment of several diseases. Therefore, nowadays various folk medicines in single, or in combination are used to treat diverse types of inflammatory and arthritic ailments (Paula et al., 2003). Medicines derived from raw materials of plants are also getting popularity due to the belief that "Green medicine" is secure with fewer side effects than the synthetic drugs (Parekh \& Chanda, 2007). Interest of ethnopharmacologists and chemists in Phytomedicines has been increased in the last decade due to their inhibitory action to propagate free radical reactions, to defend the human body from ailments and hinder lipid oxidative rancidity in food. Flavonoids and other phenolic compounds seem to be most valuable phytochemicals obtained from raw materials of herbs, seeds and fruits (Abbasi et al., 2010). Plants are award of nature to mankind to fight against microbes and diseases. Therefore, it is crucial to promote proper use of plants and to determine their potential for new medicines (Parekh and Chanda 2007). Ethnopharmacology has got much consideration and a lot of research is being carried out in this field Worldwide. Because of their widespread occurrence terrestrial angiosperms have got much attention for antimicrobial activities and other properties. However, aquatic angiosperms from rivers, lakes, etc. get less consideration and thus are ignored. Although submerged aquatic angiosperms contain promising antimicrobial agents (Morales et al., 2006; Bushmann \& Ailstok, 2006). Ikram et al. (2014) conducted and ethnobotanical study to explore the ethnomedicinal utilization of the aquatic platns of Sialkot District, Pakistan. Pistia was found to be useful in treating skin diseases, Mentha in curing digestive problems and Polygonum sp. In treating summer prickles. Therefore, the present research work was especially designed to document the plant inventory of locally used medicinal aquatic and semi-aquatic plants of Punjab, Pakistan.

\section{Materials and Methods}

This study was conceded by various visits of Wetlands of Punjab, Pakistan during the years 2008-2011. Local senior knowledgeable people and herbal healers were interviewed to get the data, i.e. local name of plants, habit and habitat, traditional uses of plants, with emphasis on therapeutic uses. The data was confirmed by frequent questioning. The fresh plants especially with flowers and fruits were collected, dried, 


\section{Sadar et al., Afr J Tradit Complement Altern Med. (2015) 12(4):9-13}

http://dx.doi.org/10.4314/ajtcam.v12i4.2

compressed, mounted and afterwards identified by Flora of Pakistan (Nasir \& Ali, 1970-1995; Ali \& Qaiser, 1995-2005). Names of plants identified were inveterated in Herbarium, Centre of Plant Conservation, University of Karachi, Karachi. The voucher specimens are placed in Herbarium, Botany Department, GC University, Lahore. The data thus obtained was verified with the existing literature on these plants.

\section{Results and Discussion}

Ethnopharmacological information collected from conventional and local people, on eighteen (18) wetland or semi-wetland plants belonging to seventeen (17) genera of the 17 families are presented in Table 1. It includes botanical and local names of the plants, their family name, part used and ethnopharmacolgical uses.

Depending upon the external and internal uses, these wetland plant species having highly ranked medicinal values were explored for the documentation of their ethnopharmacological uses. These can be classified into following different categories according to their medicinal applications and therapeutic properties:

Table 1: Medicinal uses of Wetland Plants of Punjab, Pakistan for treatment of Different Diseases

\begin{tabular}{|c|c|c|c|c|}
\hline Botanical Name & Family & Voucher Number & Part Used & Ethnopharmacological Uses \\
\hline $\begin{array}{l}\text { Alternanthera } \\
\text { sessilis (Linn.) DC. }\end{array}$ & Amaranthaceae & GC.Herb.Bot.2294 & Whole plant & $\begin{array}{l}\text { It is used to treat cough and fever, } \\
\text { wounds, eye infections and acne. }\end{array}$ \\
\hline $\begin{array}{l}\text { Bacopa moneiri } \\
\text { (Linn.) Pennell }\end{array}$ & Scrophulariaceae & GC.Herb.Bot.2295 & Whole plant & $\begin{array}{l}\text { It is used to cure a number of } \\
\text { ailments in India and Pakistan, e.g. } \\
\text { epilepsy, anxiety, depression, } \\
\text { asthma, bronchitis, cardiac and } \\
\text { digestive disorders. }\end{array}$ \\
\hline $\begin{array}{l}\text { Desmostachya } \\
\text { bipinnata (Linn.) } \\
\text { Stapf. }\end{array}$ & Poaceae/Graminae & GC.Herb.Bot.2301 & Whole plant & $\begin{array}{l}\text { It is used in diarrhea, dysentery, } \\
\text { jaundice and skin diseases. }\end{array}$ \\
\hline Eclipta alba Linn. & Compositae/Asteraceae & GC.Herb.Bot.2304 & $\begin{array}{l}\text { Leaves, Roots and } \\
\text { flowers }\end{array}$ & $\begin{array}{l}\text { Commonly prescribed by herbal } \\
\text { healers for liver disorders, also } \\
\text { used to reduce hepatic and spleen } \\
\text { ailments. Fresh juice of leaves is } \\
\text { used to improve digestion and } \\
\text { increase hunger. }\end{array}$ \\
\hline $\begin{array}{l}\text { Eicchornia } \\
\text { crassipes (Mart.) } \\
\text { Sloms }\end{array}$ & Pontederiaceae & GC.Herb.Bot.2305 & Whole plant & $\begin{array}{l}\text { It is used for cardiovascular } \\
\text { diseases and disorders of brain. } \\
\text { Leaves are diuretic that may also } \\
\text { be useful to cure cough and } \\
\text { asthma. }\end{array}$ \\
\hline $\begin{array}{l}\text { Centella asiatica } \\
\text { Linn. }\end{array}$ & Umbelliferae/Apiaceae & GC.Herb.Bot.2296 & Whole Plant & $\begin{array}{l}\text { It is employed to treat dysentery, } \\
\text { skin diseases, brain disorders, } \\
\text { tuberculosis and ulcer. It is grown } \\
\text { in ponds and water bodies as a } \\
\text { good looking foliage cover. }\end{array}$ \\
\hline $\begin{array}{l}\text { Ipomoea carnea } \\
\text { Jacq. }\end{array}$ & Convolvulaceae & GC.Herb.Bot.2308 & $\begin{array}{l}\text { Roots, Juice and } \\
\text { Leaves }\end{array}$ & $\begin{array}{l}\text { Boiled roots are used to provoke } \\
\text { menstruation while fresh juice and } \\
\text { leaves by the traditional healers for } \\
\text { skin diseases. It is grown along } \\
\text { banks of ponds and water bodies to } \\
\text { avoid soil erosion. }\end{array}$ \\
\hline I. aquatica Forsk. & Convolvulaceae & GC.Herb.Bot.2307 & Leaves & $\begin{array}{l}\text { Generally used for the treatment of } \\
\text { liver disorders. }\end{array}$ \\
\hline $\begin{array}{l}\text { Nasturtium } \\
\text { officinale } \mathrm{R} \text {. Br. }\end{array}$ & Brassicaceae/Cruciferae & GC.Herb.Bot.2313 & Whole plant & $\begin{array}{l}\text { It has been used in earliest time to } \\
\text { treat liver disorders and skin } \\
\text { ailments. }\end{array}$ \\
\hline $\begin{array}{l}\text { Nelumbo nucifera } \\
\text { Gaertn. }\end{array}$ & Nelumbonaceae & GC.Herb.Bot.2314 & Flowers & $\begin{array}{l}\text { Whole flower is used to cure liver } \\
\text { diseases and a range of other } \\
\text { ailments like fever, hypertension, } \\
\text { diarrhea, weakness etc }\end{array}$ \\
\hline $\begin{array}{l}\text { Nymphaea alba } \\
\text { Linn. }\end{array}$ & Nymphaceae & GC.Herb.Bot.2315 & Flowers & $\begin{array}{l}\text { Useful for the treatment of anxiety } \\
\text { and inhibition of renal stress. It is } \\
\text { also grown as an ornamental in } \\
\text { ponds and water bodies. }\end{array}$ \\
\hline $\begin{array}{l}\text { Phyla nodiflora } \\
\text { (Linn.) Greene }\end{array}$ & Verbenaceae & GC.Herb.Bot.2315 & Whole plant & $\begin{array}{l}\text { It is used for curing ulcer, burning } \\
\text { and asthma. }\end{array}$ \\
\hline
\end{tabular}


Sadar et al., Afr J Tradit Complement Altern Med. (2015) 12(4):9-13

http://dx.doi.org/10.4314/ajtcam.v12i4.2

\begin{tabular}{|l|c|c|c|l|}
\hline \hline Botanical Name & Family & Voucher Number & Part Used & Ethnopharmacological Uses \\
\hline $\begin{array}{l}\text { Persicaria } \\
\text { Amphibian (Linn.) }\end{array}$ & Polygonaceae & GC.Herb.Bot.2315 & $\begin{array}{l}\text { Leaves, Stems and } \\
\text { Leaves }\end{array}$ & $\begin{array}{l}\text { A combination of leaves and stems } \\
\text { is used to cure stomach pains and } \\
\text { diarrhoea. Roots are used to treat } \\
\text { cough, cold and fever. It has anti- } \\
\text { cancerous abilities as well. }\end{array}$ \\
\hline $\begin{array}{l}\text { Potamogeton } \\
\text { nodosus Poir. }\end{array}$ & Potamogetonaceae & GC.Herb.Bot.2319 & Leaves & $\begin{array}{l}\text { A pain balm is prepared by the } \\
\text { maceration of leaves. It adds } \\
\text { beauty and provides food to fish in } \\
\text { fish aquarium. }\end{array}$ \\
\hline $\begin{array}{l}\text { Ranunculus } \\
\text { muricatus Linn. }\end{array}$ & Ranunculaceae & GC.Herb.Bot.2320 & Roots and Flowers & $\begin{array}{l}\text { Commonly used to treat jaundice, } \\
\text { constipation, dropsy and swellings } \\
\text { of joints. }\end{array}$ \\
\hline $\begin{array}{l}\text { Spergularia marina } \\
\text { (Linn.) Criscb. }\end{array}$ & Caryophyllaceae \\
Roxb. & Trappinosa & GC.Herb.Bot.2325.Bot.2326 & Whole plant & $\begin{array}{l}\text { It is commonly used as an } \\
\text { antidiabetic. }\end{array}$ \\
\hline $\begin{array}{l}\text { Typha domingensis } \\
\text { Pers. }\end{array}$ & Typhaceae & GC.Herb.Bot.2327 & $\begin{array}{l}\text { Fruits are edible, sweet, nutritive, } \\
\text { appetizer and diuretic with cooling } \\
\text { effect, mainly used to treat } \\
\text { leucorrhoea, seminal weakness, } \\
\text { leprosy, fever and diarrhea. It is } \\
\text { grown as a crop because the flour } \\
\text { of its fruits has several commercial } \\
\text { uses in milk industry and as filler } \\
\text { in medicines / pharmaceutical } \\
\text { industry. }\end{array}$ \\
\hline
\end{tabular}

Aquatic plants helpful to treat respiratory diseases and fever, e.g. Alternanthera sessilis, Eichhornia crassipes, Nelumbo nucifera, Persicaria amphibian, Trapa bispinosa, Phyla nodiflora and Typha domingensis.

Aquatic plants used to reduce gastrontological disorders, e.g. Becopa moneiri, Desmostachya bipinnata, Eclipta alba, Hydrocotyl asiatica, Ipomoea aquatica, Nasturtium officinale, Nelumbo nucifera, Nymphaea alba, Phyla nodiflora, Persicaria amphibian, Ranunculus muricatus and Trapa bispinosa.

Aquatic plants useful for neurological and cardio-vascular diseases, e.g. Becopa moneiri, Eichhornia crassipes, Hydrocotyl asiatica, Nelumbo nucifera and Nymphaea alba.

Aquatic plants used against dermatological diseases e.g. Desmostachya bipinnata, Ipomoea carnea and Nasturtium officinale.

\section{APie Chart showing uses of wetland medicinal plants against different diseases}

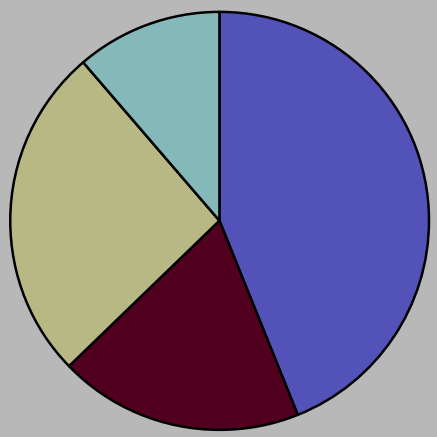

Gestrontology

Neurology and

Cardiovascular

$\square$ Respiratory

$\square$ Dematology

Figure 1 


\section{Sadar et al., Afr J Tradit Complement Altern Med. (2015) 12(4):9-13}

\section{http://dx.doi.org/10.4314/ajtcam.v12i4.2}

On the basis of above mentioned data, it looks as if Punjab was vastly diversified in having wild aquatic medicinal plants that are being used in Gastrontology (66\%), Neurology and Cardiovascular diseases (28\%), Respiratory diseases (39\%) and Dermatology (17\%) in Fig 01. In Punjab, most of the inhabitants have a rural background with an extensive experience in folk medicines as local herbalists and healers. It can be eagerly sought out after the present research work that wetlands of Punjab comprise a significant medicinal flora. The present ethnobotanical survey of aquatic plants of Punjab demands that the ethnopharmacological activities of these plants should be evaluated to support the efforts for the improvement of pharmaceutical industry in terms of natural drug resources for the synthesis of new drugs, that can be very effective against resistant pathogens. This can also lead to the protection of these plants especially from threatening and endangering factors. Most of the young people do not know about such ethnomedicinal uses of the aquatic and semi aquatic plants.

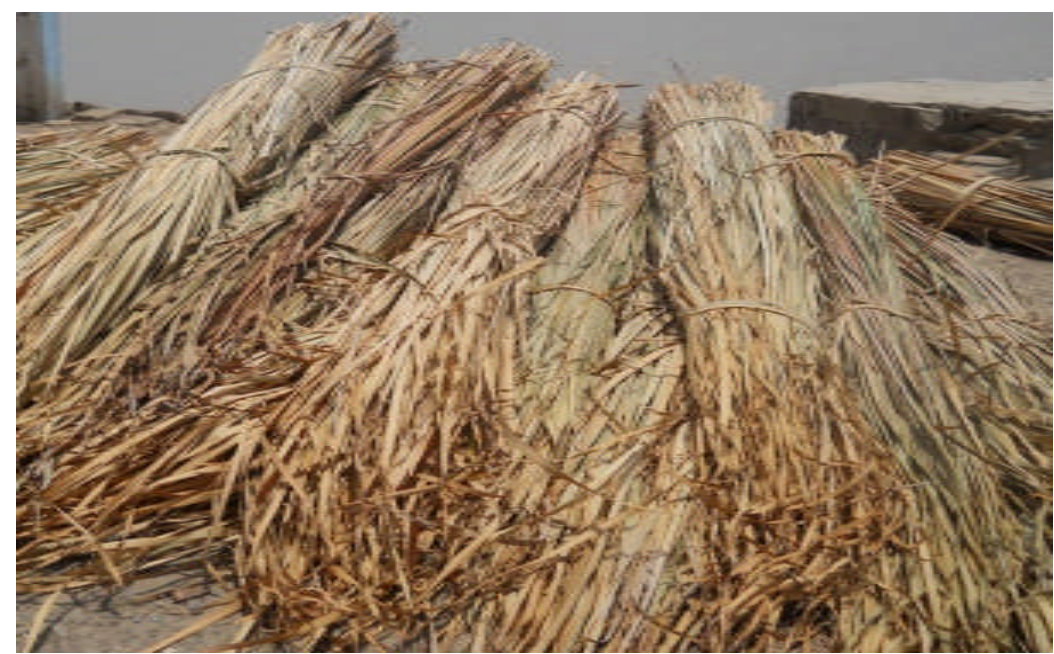

Plate 1: Bundles of Typha plants collected for making mats and baskets

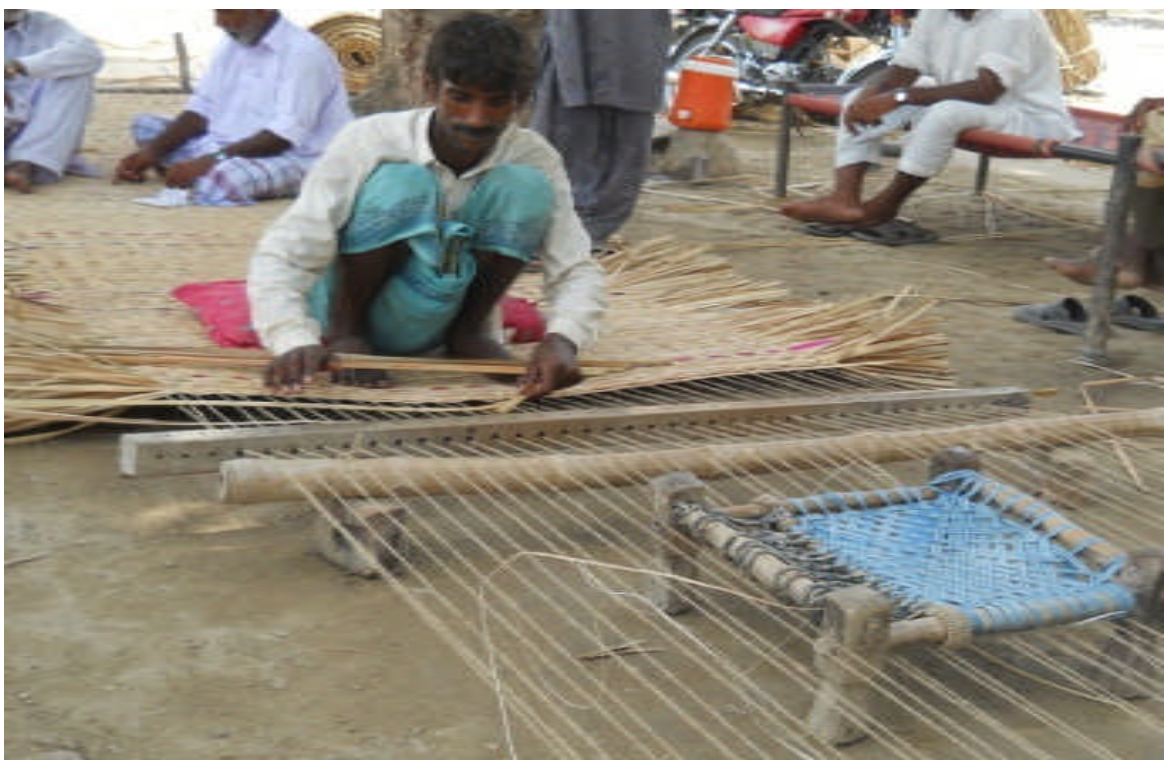

Plate 2: A person making mat from Typha plants

Other than these medicinal values, aquatic plants play an important role in water bodies, as they are the main source of food for zooplankton as Gheese and ducks eat Lemna, Potamogeton, Polygonum species etc. Songbirds use fibres of Typha species to make their nests. Typha plants are also used in making baskets and mats (Plate 1 and 2). Aquatic plants provide shelter to small animals such as aquatic insects, crustaceans, snails etc., that are ultimately used by fishes and waterfowls as food. They are also a source of food for young frogs, salamanders and fishes. Young fishes and amphibians use aquatic plants as cover in protecting them from their predators. They protect shorelines from erosion and alleviate 


\section{Sadar et al., Afr J Tradit Complement Altern Med. (2015) 12(4):9-13}

http://dx.doi.org/10.4314/ajtcam.v12i4.2

sediments for water cleaning. Nowdays, aquatic plants are getting much attention for being their use to saturate pollutants as phytoremediators and indicators of water quality, as it was recorded in some towns in Punjab during the ethnobotanical surveys of the study area. Ikram et al. (2014) conducted such studies in one of the district of Punjab Province. They also provided very signifant data on ethnopharmcology of aquatic and semiaquatic plants.

\section{References}

1. Abbasi, M.A., A. Zafar, T. Riaz, Aziz-ur Rehman, S. Arshad, D. Shahwar, M. Jahangir, S.Z. Siddiqui, T. Shahzadi and M. Ajaib. (2010). Evaluation of comparative antioxidant potential of aqueous and organic fractions of Ipomoea carnea. J. Med. Plant. Res., 4 (18): $1883-1887$.

2. Ahmad, M. (2003). Ethnobotanical and taxonomic studies of economically important plants of Tehsil Attock. M.Phil Thesis, Quaid-eUniversity, Islamabad, pp. 205-207.

3. Ali, S.I. and M. Qaiser. 1995-2005. Flora of Pakistan. Botany Department, University of Karachi, Karachi.

4. Bushmann, P.J. and M.S. Ailstok. (2006). Antibacterial compounds in estuarine submerged aquatic plants. J. Exp. Mar. Biol. Ecol., $331: 41-50$.

5. Eddouks, M., M. Maghrani, A. Lemhadri, M.L. Quahidi and H. Jouad. (2002). Ethnopharmacological survey of medicinal plants used for the treatment of Diabetes mellitus, hypertension and cardiac diseases in the Southeast region of Morocco (Tafilalet). J. Ethnopharmacol., 82: 93103.

6. Holmstedt, B. and J.G. Bruhn. (1983). Ethnopharmacology: A Challenge. J. Ethnopharmacol., 8: 251-256.

7. Ikram, S., K.H. Bhatti and M. Pervaiz. (2014). Ethnobotanical studies of aquatic plants of district Sialkot, Punjab, Pakistan. J. Med. Plants Studies, 2 (1): 2320-3862.

8. Morales, J.L., Z.O. Cantillo-Ciau, I. Sanchez-Molina and G.J. Mena-Rejon. (2006). Screening of antibacterial and antifungal activities of six marine macroalgae from coasts of Yucatan peninsula. Pharm. Biol., 44: 632-635.

9. Nasir, E. and S.I. Ali. 1970-1995. Flora of West Pakistan and Kashmir, Pakistan. Agriculture Research Council, Islamabad, Pakistan.

10. Nwar RM, Uprety Y, Burlakoti C, Chaudhary CL, Bussmann RW.(2009). Indigenous Use and Ethnopharmacology of Medicinal Plants in Farwest Nepal. Ethnobot Res Appl.;005-028.

11. Parekh, J. and S. Chanda. (2007). Antibacterial activity of the crude methanol extract of Flowers of family (Lythraceae). Braz. J. Microbiol., 38: 204-207.

12. Paula, A.C.B., L.S.S. Hayashi and J.C. Freitas. (2003). Anti-inflammatory and antispasmodic activity of Ipomoea imperati (Vahl.) Griseb. (Convolvulaceae). Braz.. J. Med. Bio. Res., 36: 105-112. 